\title{
Electron-microscopical Study on Fine Structures of Diatom Frustules XIII
}

\author{
by Haruo OKUnO* \\ 奥 野 春 雄：電子敫微鏡による珪藻款微細龩造の研究 XIII
}

Received December 8, 1954

Coscinodiscus concinnus W. Smith (Text figs. 1, 2-A, 3; P1. I, figs. 1-6), Synop. Brit. Diat. 2, p. 85 (1856); A. Schmidt, Atlas, pl. 114, figs. 8, 9 (1886); Hustedt, Kieselalg. 1, p. 441, figs. 241-242 (1930); Mills, Index Diat. p. 463 (1933); Cupp, Bull. Scrips Inst. Ocean. 5, p. 58, fig. 22 (1943); Cleve-Euler, K. V. A. Handl. 2, no. 1, p. 68, figs. 108 a-f (1951).

L. M. S. ${ }^{1)}$ Frustules drum-shaped, 200-380 (150-500) $\mu$ in diameter, with convex, in the center sometimes slightly depressed, valve surface (Text fig. 1). Pervalvar

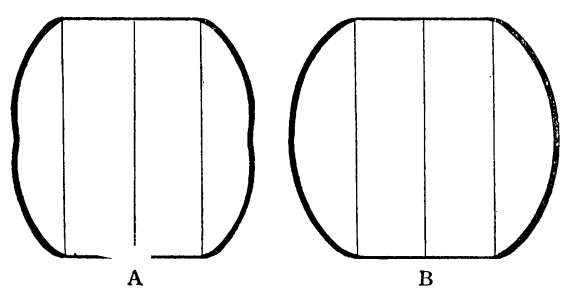

Text fig. 1. Two types of frustules of Coscinodiscus concinnus. A, Frustule with depressed valve-center. B, Frustule with non-depressed valve-center. axis about $200-330 \mu$ long, girdle about $50-90 \mu$ high. Valves in dry preparation bright brownish yellow. In our specimens, central rosette distinct (Pl. I, fig. 1). Frustule pores arranged in radiating and secondary spiral rows, 9-10 in $10 \mu$, decreasing to 12 at the margin. Radiating hyaline lines and marginal spinulae distinct, about 1 in $10 \mu$. Two small asymmetrical processes present.

Preparation: Direct preparation without thermal or chemical treatment.

E. M. S.2) Frustule pores in the valve surface are loculi. The loculus regular or scalene hexagonal (one side about $0.4-0.6 \mu$ long), with outer sieve, inner closing, and lateral membranes (Text figs. 2-A, 3). The sieve membrane (sm), except on its margin has many sieve pores ( $s p$ ). Sieve pores about 10-13 in $1 \mu$, triangular to polygonal with irregularly serrate borders, and arranged in somewhat concentrical rows. The inner closing membrane $(\mathrm{cm})$ is very thin (somewhat penetrable to the electron beam) and has a central round opening (o) about $0.4-0.55 \mu$ in diameter. The inner border of the closing membrane ss electron-optically a little thicker than the other part. The lateral membrane $(l m)$ is about $0.2-0.5 \mu$ high, six-sided, each

* Botanical Laboratory, Kyoto University of Industrial Arts and Textile Fibers, Kamikyôku, Kyoto. 京都工芸繊維大学繊維学部植物学研究窒

1) L. M.S.: Light-microscopic structure

2) E. M.S.: Electron-microscopic structure 


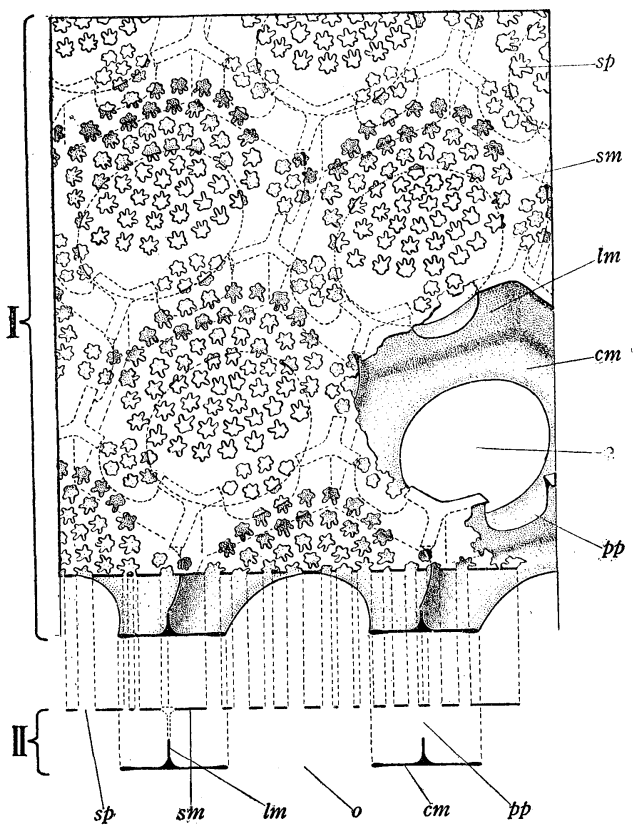

A

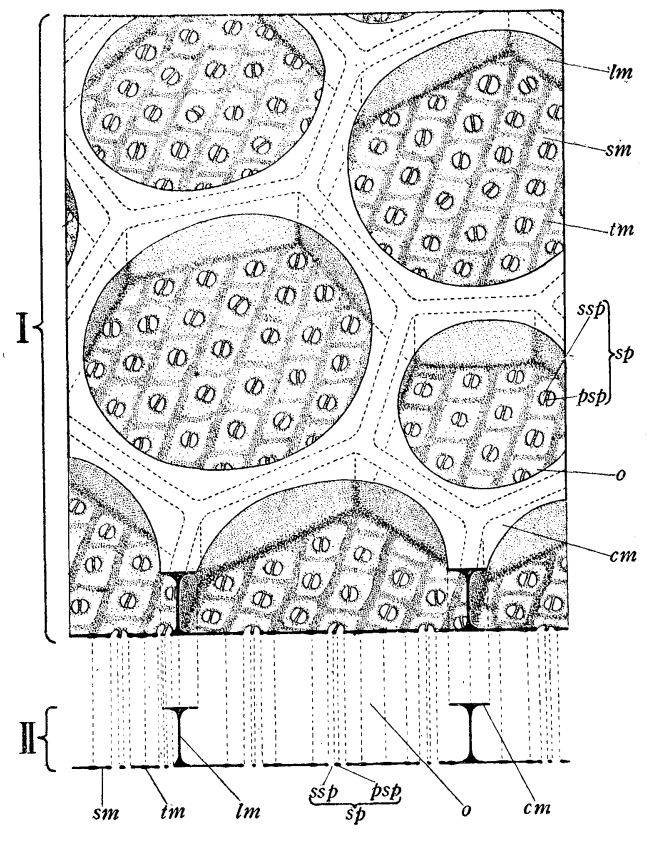

B

Text fig. 2. Diagramatic representation of loculi of Coscinodiscus concinnus (A), and Stephanopyxis palmeriana (B). I, View from obliquely above. II, Longitudinal (pervalvar) section. $\mathrm{cm}$, Closing membrane. $\mathrm{lm}$, Lateral membrane. $o$, Opening of closing membrane. $p p$, Pass pore. $p s p$, Partition of secondary sieve pore. $s m$, Sieve membrane. $s p$, Sieve pore. $s s p$, Secondary sieve pore. $t m$, Thickening of sieve membrane.

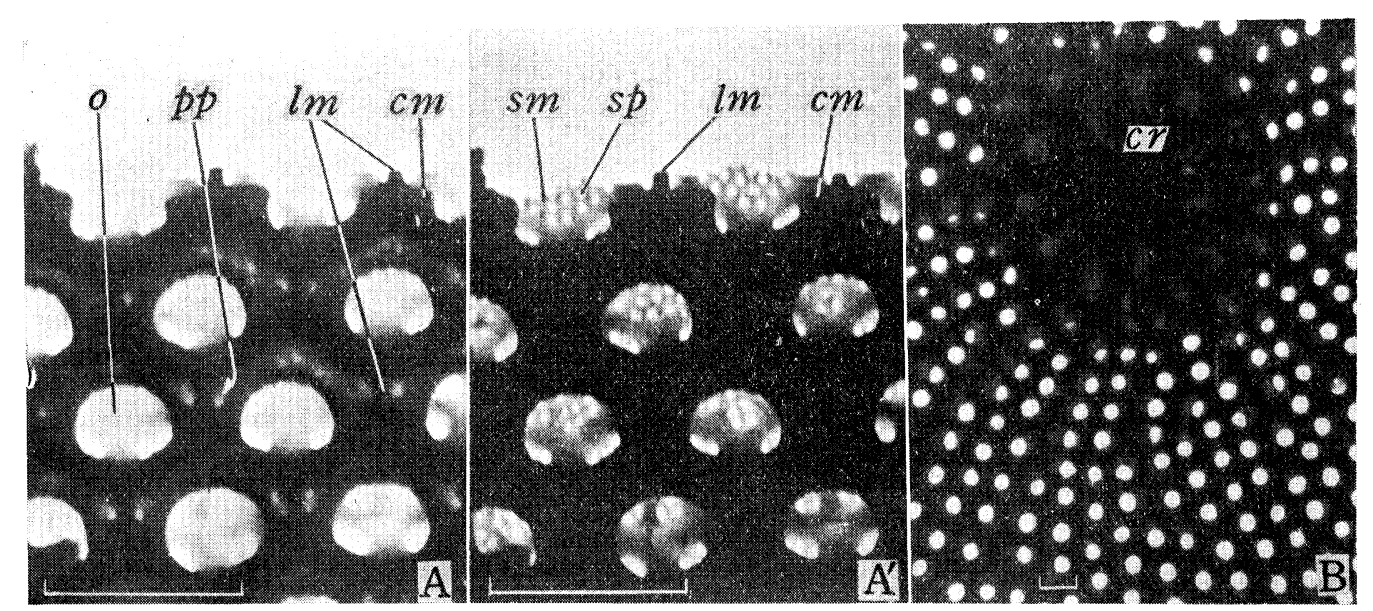

Text fig. 3. Coscmodiscus concinnus. A, A', Same portion of a broken valve (A, Light print. $\mathrm{A}^{\prime}$, Dark print). B, Central part of valve. $\mathrm{cm}$, Closing membrane (inner membrane). $\mathrm{cr}$, Central rosette. $l m$, Lateral membrane. $o$, Opening of closing membrane. $p p$, Pass pore. $s m$,

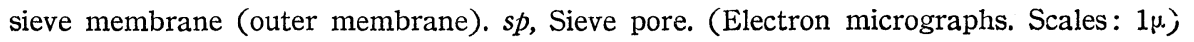


side with an angular pass pore $(p p)$ about $0.1-0.2 \mu$ broad, through which the neighbouring loculi communicate with each other.

Loculi in the girdle are about 18-20 and 20-22 in $10 \mu$ respectively in longitudinal and oblique rows. Loculi hexagonal, with outer and inner round opening respectively about $0.2-0.25 \mu$ and $0.15-0.2 \mu$ in diameter. The outer opening of the loculus lacks the closing sieve membrane.

Habitat: Marine, planktonic. Osaka Bay (Off the coast of Kariya, Awaji Island). (Okuno, No. m863. Aug. 1953).

Stephanopyxis palmeriana (Greville) Grunow (Text fig. 2-B; Pl. II, figs. la-e), Okuno, Bot. Mag. Tokyo, 63, p. 97, pl. 1, fig. 1' (1950); Cupp, Bull. Scrips Inst. Ocean. 5, p, 40, fig. 4 (1943).

Preparation: Direct and formval preparations without thermal or chemical treatment.

In my paper (1950) listed above, I reported some electron-microscopic structure of the porous sieve membrane of the present species. By my recent research, further details of fine structure of the loculus were revealed under the electron microscope. Here the new details in addition to the general structure will be presented. Loculi are large in the valve, small in the mantle, and smallest near the girdle line, respectively about $1.5-3,4-5,5-6$ in $10 \mu$. Loculi usually hexagonal, at the girdle line exceptionally pentagonal, all opening outwards ${ }^{3}$ almost freely, and closing inwards by finely porous sieve membranes (Text fig. 2-B; Pl. II, fig. 1d). The outer closing membrane $(\mathrm{cm})$ of the loculus marginal and narrow; in the center of the valve surface it is remarkably reduced in breadth and indistinct (Pl. II, fig. 1b). The central opening $(o)$ of the outer closing membrane usually round to elliptic; in the valve surface it is large and nearly polygonal. The lateral membrane $(\mathrm{lm})$ of the loculus very thin, not porous, and about $0.4-0.5 \mu$ high. The inner sieve membrane $(\mathrm{sm})$ has netveined rectangular, rarely polygonal thickenings $(\mathrm{tm})$. The thickenings or the meshes in the whole mantle are arranged in common longitudinal parallel rows about 4-5 in $10 \mu$, and in the whole valve surface they are arranged in common radiating rows about $4-5$ in $10 \mu$. Both in valve and mantle, the arrangement of thickenings or meshes is quite independent of that of the loculi. A mesh, in its center, has a round to elliptic sieve pore $(s p)$ about $50-100 \mathrm{~m} \mu$ in diameter, which is divided by a delicate partition ( $p s p$ ) into two semicircular secondary sieve pores (ssp). In the mantle, many of the partitions are parallel to the pervalvar axis, and in the valve, usually parallel to the radius of the valve. At the girdle line ( $g l$ ), each of the sieve membranes of about every second to fourth loculi has a linear stigma about $700 \mathrm{~m} \mu$ long and about $100 \mathrm{~m} \mu$ broad (P1. II, fig. 1e-st). Spines at the valve margin are hollow, and their walls are electron-optically non-porous (P1. II, fig. 1c).

Habitat: Marine, planktonic. $39^{\circ} \mathrm{N}$; $153^{\circ} \mathrm{E}$. (Okuno, No. m 977-8. Nov. 1952. Collected by R. Marumo.)

3) Cf. Cleve-Euler. K. V. A. H. 2, no. 1, p. 36 (1951) 
Stephanopyxis nipponica Gran and Yendo') (Pl. II, figs. 2a, b)

This species differs from St. palmeriana mainly in its smaller, oblong or subspherical frustules, but electron-optically is almost the same in the structure of loculi as St. palmeriana. In the present electron-microscopy, the netveined thickenings of sieve membranes and the partitions in sieve pores were not found. Stigma of the loculus at the girdle line is papillar, quite diffeient in shape from that of the previous species. Spines at the valve margin are hollow, and their walls are non:porous as in the previous species.

Habitat: Marine, planktonic. $50^{\circ} 54^{\prime} \mathrm{N} ; 178^{\circ} 53^{\prime}$ W. (Okuno, No. m698. May, 1952). $41^{\circ} 58^{\prime} \mathrm{N}$; $145^{\circ} 40^{\prime} \mathrm{E}$. (Okuno, No. m975-6. Jan. 1954). (Collected by R. Marumo).

\section{Literature ${ }^{5)}$}

1. Brockmann, C. Schr. Vereins Naiturk. Unterweser, N.F. VIII, 6, VIII, Beit. Naturk. N. W. Deut. 3 (1952) 2. Helmcke, J. G. \& Krieger, W. Zeitschr. wiss. Mikros. u. mikros. Tech. 60: 197 (1951) 3. ….... Verh. Deut. Zool. Ges. Wilhelmshaven. $438(1951) 4 . \quad$. Ber. Deut. Bot. Ges. 65:69 (1952) 5. - - Diatomeenschalen im elektronen-mikroskopischen Bild. I, II $(1953,54)^{6)}$ 6. Helmcke, J. G. Naturwiss. H. 11:254 (1954) 7. Hustedt, F. Arch. Hydrobiol. $47: 295$ (1952) 8. Kolbe, R. W. Sv. Bot. Tid. 45:636 (1951) 9. Okuno, H. Journ. Jap. Bot. 26: 305, 27:46, 347, 28:171 29: 18, 271 (1951-54) 10. . . Bot. Mag. Tokyo, 67: 172 (1954) 11. -.......-. Trans Proc. Palaeont. Soc. Jap. N. S. 13: 125, 14: 143 (1954) 12. Wiseman, J. D. H. \& Hendey, J. I. Deep-Sea Res. 1:47 (1953)

4) Mills, Index Diat. p. 1488 (1934); Cupp, Bull. Scrips Inst. Ocean. 5, p. 43, fig. 5 (1943)

5) Cf. This Magazine, 62: 139 (1949), 63: 106 (1950), $67: 177$ (1954)

6) The present writer has not yet seen these publications. 


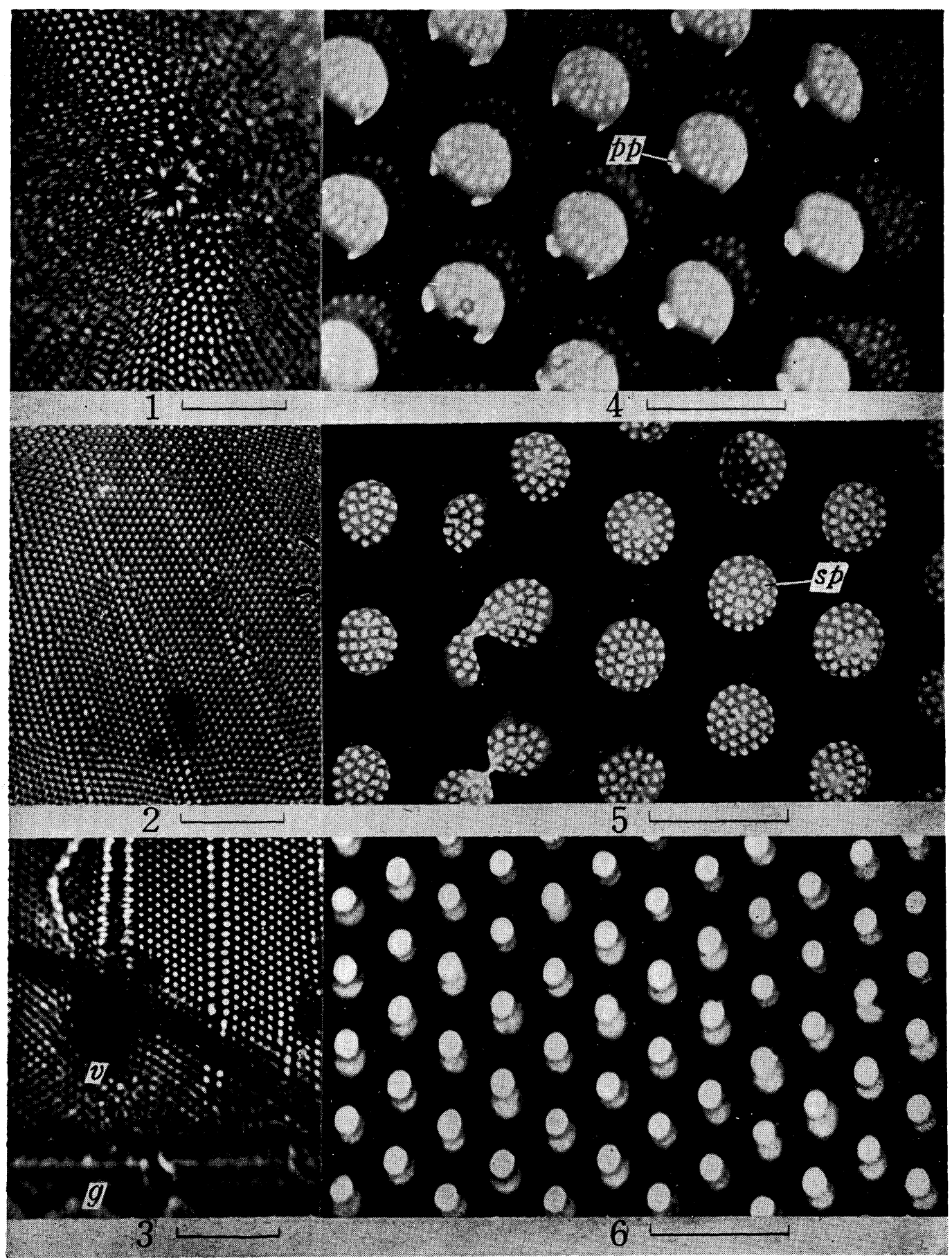

Figs. 1-6, Coscinodiscus concinnus 1, Central part of valve, showing central rosette. 2, Part of valve near central area, showing 'hyaline lines'. 3, Portion of margin of valve ( $v$ ) and girdle $(g)$. 4, Portion of valve, viewed obliquely from inside; note the pass pore $(p p)$ of loculus. 5 , Portion of valve, viewed vertically; note the sieve pore $(s p)$. 6, Portion of girdle viewed obliquely from inside, showing ioculi. (1-3, Light micrographs. Scales: $10 \mu$. 4-6, Electron micrographs. Scales: $1 \mu$. 


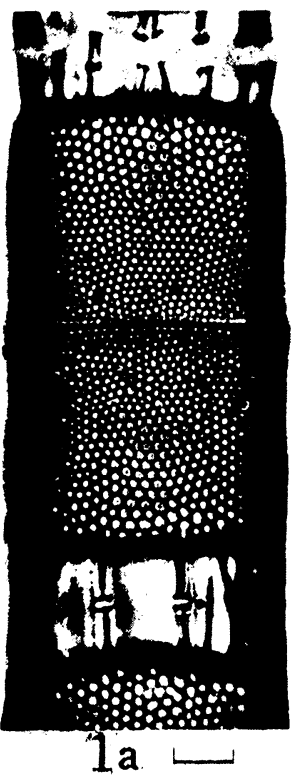

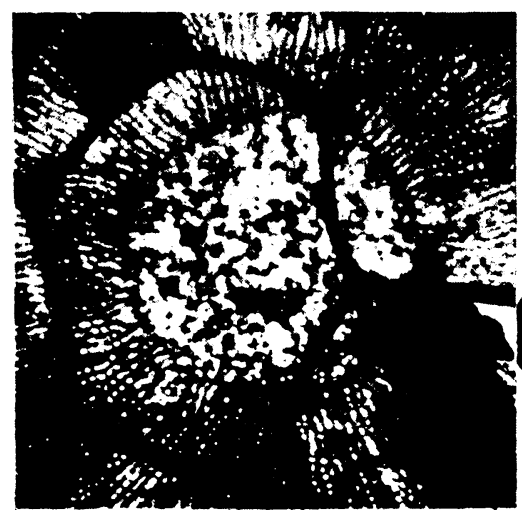

$1 b^{\prime}-$
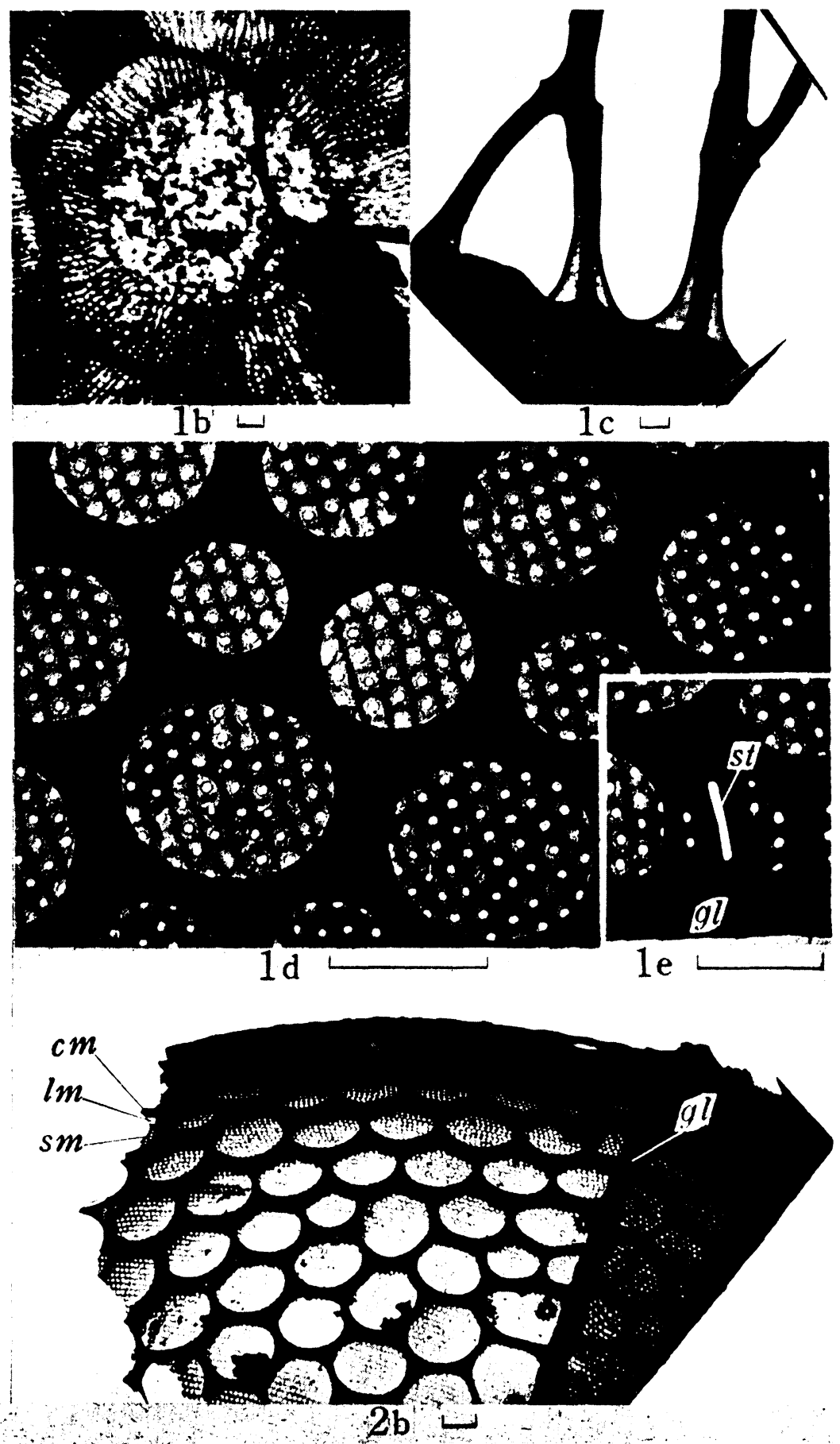

$2 \mathrm{a}$

Figs. 1a-e, Stephanopyxis palmeriana. la, Girdle view. 1b, Central part of valve. 1c, Spines. 1d, Portion of mantle. le, Loculus with stigma (st) near the girdle line ( $g l$ ). 2a, b, St. nipponica. $2 \mathrm{a}$, Girdle view, $2 \mathrm{~b}$, Portion of valve; note left side where broken loculi opening outwards are demonstrated. $\mathrm{cm}$, Closing membrane. $g l$, Girdle line. $l m$, Lateral membrane. $s m$, Sieve mem-

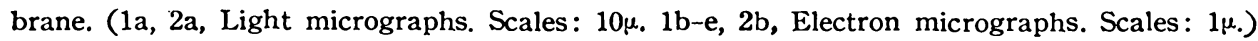

